\title{
THE HYDROPHOBICITY AND THE ANTIBACTERIAL ACTIVITY OF POLYESTER MODIFIED WITH SILVER NANOPARTICLE AND HEXADECYLTRIMETHOXYSILANE
}

\section{HIDROFOBISITAS DAN AKTIVITAS ANTIBAKTERI POLIESTER HASIL MODIFIKASI DENGAN NANOPARTIKEL PERAK DAN HEKSADESILTRIMETOKSISILAN}

\author{
Eli Rohaeti ${ }^{1 *}$, Anna Rakhmawati ${ }^{2}$ \\ ${ }^{1}$ Jurusan Pendidikan Kimia, FMIPA Universitas Negeri Yogyakarta, Yogyakarta, Indonesia \\ ${ }^{2}$ Jurusan Pendidikan Biologi, FMIPA Universitas Negeri Yogyakarta, Yogyakarta, Indonesia \\ *email: eli_rohaeti@uny.ac.id; rohaetieli@yahoo.com
}

Received December 29, 2016; Accepted May 25, 2017; Available online May 30, 2017

\begin{abstract}
The objective of this research was to study hydrophobicity and antibacterial activity of polyester fibers before and after modification by using silver nanoparticles as antibacterial agent and hexadecyltrimethoxysilane (HDTMS) as a self-cleaning agent. The research was conducted in stages, preparation of silver nanoparticles, deposition of silver nanoparticles on polyester fiber, modification of polyester fiber through the addition HDTMS, and characterization. Modification of polyester fibers with silver nanoparticles and HDTMS was conducted through dipping method, followed by curing. Characterization was performed by testing the contact angle and antibacterial activity against Staphylococcus aureus ATCC 25923 and Escherichia coli ATCC 35218 . Silver nanoparticles have been prepared by adding sodium citrate and polyvinylalcohol as a stabilizer. The addition of silver nanoparticles decreased hydrophobicity of polyester fibers without and with modification. Modification with HDTMS increased the hydrophobicity of polyester fibers. Modification with silver nanoparticles and HDTMS increased antibacterial activity of polyester fabrics. Statistic analysis showed that there were significant differences in the antibacterial activity of polyester fibers against Staphylococcus aureus ATCC 25923 and Escherichia coli ATCC 35218.
\end{abstract}

Keywords: antibacterial activity, hydrophobicity, silver nanoparticles, polyester fabric.

\section{ABSTRAK}

Penelitian ini bertujuan untuk mempelajari hidrofobisitas dan aktivitas antibakteri serat poliester sebelum dan sesudah modifikasi dengan penambahan bahan antibakteri berupa nanopartikel perak dan penambahan bahan antikotor berupa heksadesiltrimetoksisilan (HDTMS). Tahapan penelitian yang dilakukan meliputi preparasi nanopartikel perak secara kimia, deposit nanopartikel perak pada serat poliester, modifikasi serat polyester melalui penambahan HDTMS, dan karakterisasi. Modifikasi serat poliester dengan nanopartikel perak dan HDTMS dilakukan melalui metode pencelupan yang dilanjutkan dengan proses curing. Karakterisasi dilakukan melalui uji sudut kontak dan uji aktivitas antibakteri terhadap bakteri Staphylococcus aureus ATCC 25923 dan Escherichia Coli ATCC 35218. Nanopartikel perak dapat dipreparasi melalui penambahan natrium sitrat dan penstabil polivinilalkohol. Penambahan nanopartikel perak menurunkan sifat hidrofobisitas dari serat poliester tanpa dan dengan modifikasi. Penambahan heksadesiltrimetoksisilan meningkatkan hidrofobisitas serat poliester. Modifikasi dengan nanopartikel perak dan HDTMS meningkatkan aktivitas antibakteri serat poliester terhadap bakteri Staphylococcus aureus ATCC 25923 dan Escherichia Coli ATCC 35218. Analisis statistik menunjukkan adanya perbedaan yang signifikan dalam hal aktivitas antibakteri serat poliester terhadap bakteri Staphylococcus aureus ATCC 25923 dan Escherichia Coli ATCC 35218.

Kata kunci : aktivitas antibakteri, hidrofobisitas, nanopartikel perak, serat poliester.

\section{INTRODUCTION}

Pollution is one of the causes of contamination of the natural environment in Indonesia. Air pollution makes the air temperature is becoming increasingly high. The hot air causes the body to sweat more and more dust stick. This condition speeds the growth of many types of bacteria that are pathogenic for the human body. These bacteria can cause various diseases to the human body.

Clothing is one of the outer protection for the body from environmental including the bacteria that grow in a skin as well as clothing was worn. Therefore, it needs fabrics that can 
protect the human body from bacteria effectively. One effort to improve the quality and quantity of textile materials is to conduct modifications on textiles with properties hydrophobic and antibacterial.

Textile applications with hydrophobic and antibacterial properties have been widely used in the medical field as a base for dressings, protective clothing for patients, physicians, and as well as in the military was used for soldiers' uniforms (El-Khatib, 2012). However, until now the textile material with antibacterial and hydrophobic properties is not found on the market. Demand for textile products with antibacteria and hydrophobic properties still dependent on foreign material with a high price. The need for textiles with antibacterial and hydrophobic properties that encourage increased import of the material of the cloth.

The background of this research is dependence on imported products, high-value import, high prices, and the demand for textile with antibacterial and hydrophobic properties. Production of textile materials with antibacterial and hydrophobic properties in the country is expected to reduce import value of textile materials Indonesia and can meet the demand for clothing, especially textile materials with antibacterial and hydrophobic properties.

Nanoparticle technology can be applied in the textile industry to modify various textile fibers that have antibacterial properties. The silver nanoparticle is one of nanostructured particle which has effective antibacterial activity (Haryono and Harmami, 2010). Silver nanoparticles can inhibit the growth of bacteria Escherichia coli, Bacillus subtilis, Staphylococcus aureus as disclosed by Ariyanta, Wahyuni, and Priatmoko (2014), and Pseudomonas aeruginosa (Guzman, Dille, and Godet, 2012).

Some of the literature revealed that the antibacterial properties of textiles can be developed by coating of silver nanoparticles in textile materials, for example on cotton (Shateri-Khalilabad and Yazdanshenas, 2013), silk (Zhang, Liu, Gao, and Chen, 2014), wool (Boroumand, Montazer, Simon, Liesiene, Šaponjic, and Dutschk, 2015, polyester (Kavitha and Dasan, 2013). The antibacterial activity is influenced by the size of the silver particles (Haryono and Harmami, 2010). The smaller the size of the nanoparticle, its activity increases. The optimal size of silver nanoparticles is small size with a distribution is very narrow (Crespo, García-Barrasa, López-de-Luzuriaga, and Monge, 2012). Also, the low concentration of silver nanoparticles is safe to use on the human body because the silver nanoparticles are not toxic to humans (Rai, Yadav, and Gade 2009). Preparation of silver nanoparticles can be done by various methods including: sputtering (Jiang, Qin, and Zhang, 2010), reduction with a compound organic (Ahmad, Tay, Shameli, Hussein, and Lim, 2011), reduction with a fungi (Duran and Marcato, 2007), and reduction with a sodium citrate solution (Ariyanta, Wahyuni, and Priatmoko, 2014).

Hydrophobicity of the textile affect the properties of the textile. Textiles with hydrophobic properties are often referred to as self-cleaning textiles. The hydrophobic properties of textile materials can be developed by using a silane-based compound. Fiber materials are coated by the silane with low surface energy, are proven to increase the hydrophobicity of the fiber (Khalil-Abad and Yazdanshenas, 2010; Xue, Chen, Yin, Jia, Jian-Zhong, 2012). This coating is inspired from the nature of the plant leaf surface Nelumbo nucifera or lotus is often called hydrophobic. Some types of silane-based compounds have been used to modify textiles such as $\gamma$-methacryloxypropyl trimethoxy silane (MAPS) and hexamethyldisilazen (HMDS) (Gao, Watanabe, Nakane, and Zhao, 2016); perfluorooctylated quaternary ammonium silane coupling agent (PFSC) ( $\mathrm{Yu}$, $\mathrm{Gu}$, Meng, and Qimg, 2007); polymethylhydroxysilosane (PMHS) and tetraethoxysilane (TEOS) (Guo, Zhai, Xiao, and An, 2015); and Hexadecyltrimethoxysilane (HDTMS) (Xue et al., 2012).

Polyester is known as Dacron or Terelene in the trade. Polyester fiber is one kind of synthetic fiber which strong, durable, and not wrinkled. Polyesters are also often used as a mixture of natural fibers such as cotton, wool or rayon to obtain fabrics with superior quality. Naturally polyester has hydrophobic properties that are often used as a sports clothing, underwear, bed linen, and medical garments. Textiles that are resistant to bacteria, viruses, fungi, and other harmful microorganisms are also often needed as raw materials for sports clothing, underwear, bed linen, and medical garments (Hassan, Qashqary, Hassan, Shady, and Alansary, 2012). 
Based on the background of the problem, the research on the modification of polyester fibers to improve the antibacterial properties and hydrophobic has been conducted. The using of silver nanoparticles and silane-based compound to coat the polyester fiber is conducted to improve the antibacterial properties and hydrophobic of polyester fiber. Preparation of silver nanoparticles has been performed by the reduction method using $\mathrm{AgNO}_{3}$ solution. The polyester fiber is coated with HDTMS compound by the immersion method. The formation of silver nanoparticles was analyzed by using UV-Vis spectrophotometer and the hydrophobic properties by measuring the angle of contact, and the antibacterial activity of the polyester fiber by measuring clear zone. The objective of this study was to determine the characteristics of polyester fibers with and without modification using silver nanoparticles and Hexadecyltrimethoxysilane.

\section{MATERIALS AND METHODS}

\section{Equipment and Materials}

The UV-Vis spectrophotometer (Shimadzu UV-2400PC Series), Laminar Air Flow (LAF), incubator, oven, autoclaves, regulators of nitrogen gas, shaker, hot plate magnetic stirrer, analytical balance, camera, glasswares, Bunsen, calipers, tip pippet, thermometer, Drigalsky, and ose have been used in this research.

The Polyester cloth was purchased from the fabric store in Yogyakarta. Silver nitrate, trisodium citrate, polyvinyl alcohol (PVA), ethanol, acetone, and hexadecyltrimethoxysilane (HDTMS) were purchased as commercial products and used as they were without any further purification. Nutrient Agar (NA) and Nutrient Broth (NB) were purchased from Oxoid. Nitrogen gas was purchased from PT Samator, Yogyakarta. Staphylococcus aureus ATCC 25923 and Eschericia coli 32518 were obtained from a collection of Faculty of Medicine, Gadjah Mada University.

\section{Procedures \\ Preparation of Silver Nanoparticle $(N)$}

Silver nanoparticle was prepared by using $0.001 \mathrm{M}$ silver nitrate solution, $10 \%$ trisodium citrate solution as a reductor, and $0.2 \%$ PVA solution as a stabilizer (Haryono, Sondari, Harmami, dan Randy, 2008). PVA solution and silver nitrate solution were added into three neck flask then refluxed for 5 hours (Saputra, Haryono, Laksmono, and Anshari, 2011). Trisodium citrate solution was added dropwise. Gas $\mathrm{N}_{2}$ was flowing until reflux process finished. Heating and flowing of $\mathrm{N}_{2}$ gas were stopped if already transformed solution into a yellow, but stirring was still done until room temperature reached. Then, silver nanoparticles were characterized using $\mathrm{UV}-\mathrm{V}$ is spectrophotometer.

Application of Silver Nanoparticles on Polyester Fiber (Polyester-Ag)

The polyester fabric was cut to the size of $10 \mathrm{~cm} \times 10 \mathrm{~cm}$. Polyester fiber was immersed in colloidal of silver nanoparticle then twisted around using a shaker at $150 \mathrm{rpm}$ for 24 hours and dried at $70{ }^{\circ} \mathrm{C}$.

\section{Modification Surface Polyester Fiber with Compound HDTMS (Polyester-HDTMS)}

The polyester and the polyester-Ag were immersed into the $4 \%$ of HDTMS solution. The reacting process between HDTMS and ethanol solution was carried out at room temperature for 6 hours. The polyester and polyester - Ag which immersed in silane solution were twisted at $150 \mathrm{rpm}$ for 60 minutes. Then, polyester fiber before and after modification were analyzed including antibacterial activity test and contact angle test.

The polyesters which prepared in this study were polyester fiber, polyester-Ag, polyester-HDTMS, and polyester-AgHDTMS (Table 1).

Tabel 1. The variation of the polyester fiber without and with modification

\begin{tabular}{cll}
\hline No & \multicolumn{1}{c}{ Type of Sample } & \multicolumn{1}{c}{ Code } \\
\hline 1 & Polyester without modification & P \\
2 & Polyester with adding silver nanoparticles & P-Ag \\
3 & Polyester with adding HDTMS & P-HDTMS \\
4 & Polyester with adding silver nanoparticles and & P-Ag-HDTMS \\
& HDTMS & \\
\hline
\end{tabular}




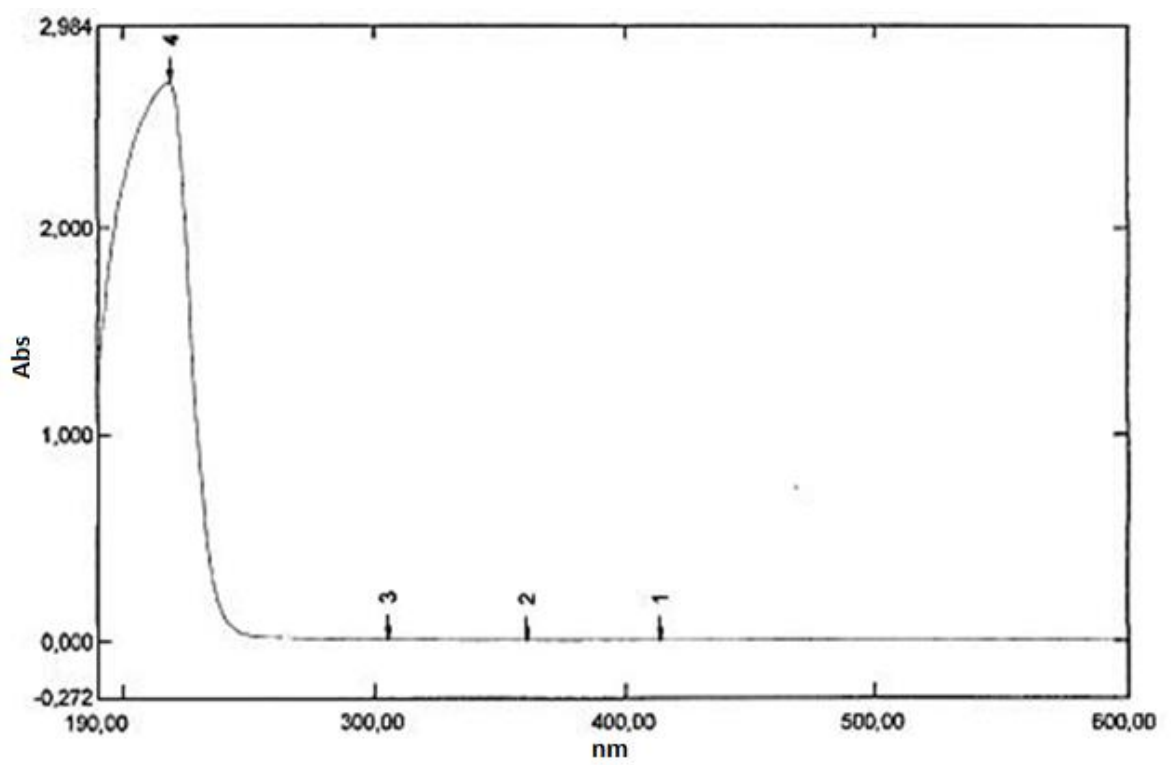

(a)

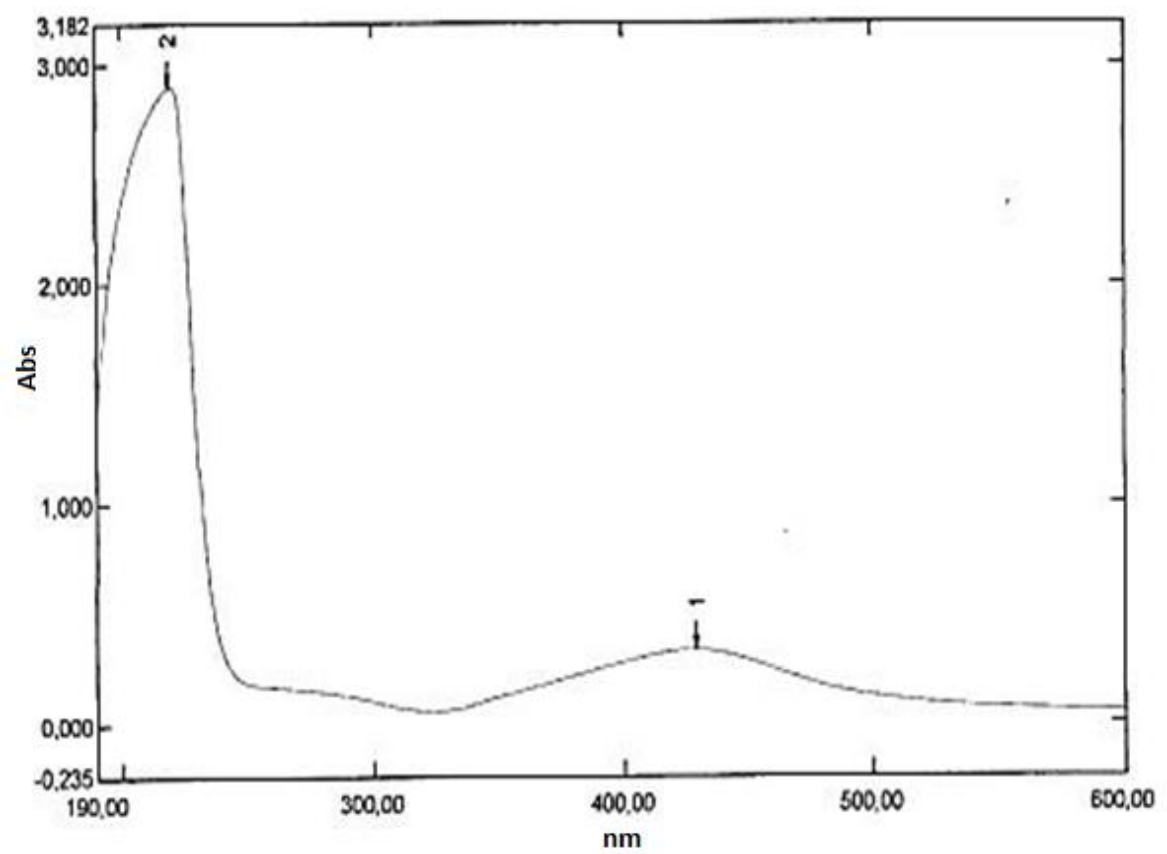

(b)

Figure 1. The UV-Vis Spectra of $1 \times 10^{-3} \mathrm{M} \mathrm{AgNO}_{3}$ Solution (a), Colloidal of Silver Nanoparticle (b)

\section{Characterization}

The characteristic of silver nanoparticle was performed using UV-Vis spectrophotometer (Shimadzu UV-2400PC series, Japan). An absorbance of silver nitrate solution $1 \times 10^{-3} \mathrm{M}$ and silver nanoparticle were measured using a reference solution of distilled water. The properties anti-dirty (hydrophobic) of the samples were determined by measuring the water contact angle $(\theta)$ between the fluid and the sample surface. Samples were placed on the surface of a table or a flat board and micropipette is placed on the top then paired with the upright. By using a pipette, liquid dripped from a height of $1 \mathrm{~cm}$ of the sample. Once the liquid dropped, the contact angle shooting was done. The images processed using software to determine the contact angle between the liquid surface of the sample.

Antibacterial Activity of the sample of $\mathrm{P}$, P-Ag, P-HDTMS, and P-Ag-HDTMS performed against Escherichia coli ATCC 35218 and Staphylococcus aureus ATCC 25923 by measuring the clear zone is formed around the sample. Antibacterial activity was 
performed by preparing bacterial growth media such as Nutrient Agar (NA) and Nutrient Broth (NB) by dissolving NA and NB in distilled water. All the tools and media for growing bacteria were sterilized in an autoclave. Rejuvenation of Staphylococcus aureus ATCC 25923 and Escherichia coli ATCC 32518 was conducted on an agar medium NA and incubated for 24 hours at room temperature.

Staphylococcus aureus 25923 and Escherichia coli ATCC 32518 which has been rejuvenated for 24 hours and then inoculated into a liquid medium NB in the culture bottles and incubated for 24 hours at a temperature of $37{ }^{\circ} \mathrm{C}$. Meanwhile, NA poured into each petridish and waited about 24 hours anyway. Petridish had been ascertained that no contamination is then coated NB which had been overgrown with bacteria and leveled by using Drygalsky. Each sample was cut with a diameter of $0.6 \mathrm{~cm}$, inserted into the petri dish and allowed in the incubator for 24 hours, then observed a clear zone every three hours for 96 hours. The inhibition zone was measured by using calipers.

\section{RESULTS AND DISCUSSION}

\section{The Characteristics of Silver Nanoparticles and P-Ag}

The silver nanoparticles have been successfully prepared in the colloidal form

$$
4 \mathrm{Ag}^{+}{ }_{(\mathrm{aq})}+\mathrm{C}_{6} \mathrm{H}_{5} \mathrm{O}_{7} \mathrm{Na}_{3(\mathrm{aq})}+2 \mathrm{H}_{2} \mathrm{O}_{(\mathrm{l})} \longrightarrow 4 \mathrm{Ag}^{0}{ }_{(\mathrm{s})}+\mathrm{C}_{6} \mathrm{H}_{5} \mathrm{O}_{7} \mathrm{H}_{3(\mathrm{aq})}+3 \mathrm{Na}^{+}{ }_{(\mathrm{aq})}+\mathrm{H}^{+}{ }_{(\mathrm{aq})}+\mathrm{O}_{2(\mathrm{~g})}
$$

with yellow color. The Equation 1 shows reduction reaction that occurs in preparation silver nanoparticle (Haryono and Sri Budi Harmami, 2010). Figure 1 shows the UV-Vis spectra of silver nitrate solution and colloidal of silver nanoparticles. The UV-Vis spectrum of colloidal of silver nanoparticles shows absorption peak at wavelength $429 \mathrm{~nm}$ and the absorbance of 0.333 which suggests that the $\mathrm{Ag}^{+}$has reduced into $\mathrm{Ag}^{0}$ (Junaidi, Wahyudi, and Umaningrum 2015). The polyester fiber which has been deposited by silver nanoparticles $(\mathrm{P}-\mathrm{Ag})$ turns into more brown color than the pure polyester fiber (P) (Figure 2).

\section{Hydrophobic Properties of Polyester}

Hydrophobic properties of samples was determined by measuring contact angle (Figure 3 dan Table 2). The hydrophobic surface has a contact angle more of $90^{\circ}$ (Arkles, 2006). Based on Table 2 can be seen that P-HDTMS has the highest contact angle. Thus, HDTMS compound can increase contact angle of polyester. It can be caused HDTMS compounds interact with a material surface through the formation of covalent bonding and lowering the critic surface tension until smaller than critic surface tension of the water. Consequently, surface of polyester fiber becomes more hydrophobic.

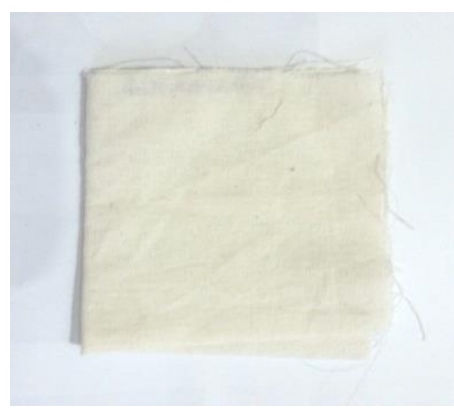

(a)

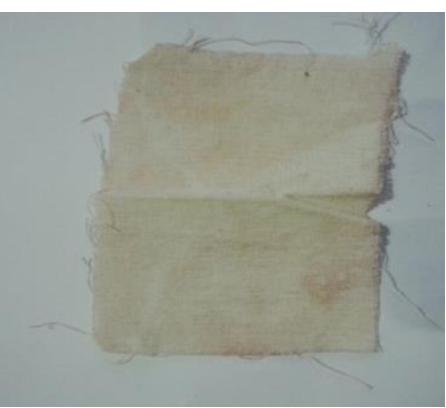

(b)

Figure 2. Polyester Fiber (a); and Polyester Fiber with Adding Silver Nanoparticles (b)

Table 2. Contact Angle of Polyester without and with Modification

\begin{tabular}{ccc}
\hline No & Type of Sample & Contact Angle $\left(^{0}\right)$ \\
\hline 1 & P & 105.5 \\
2 & P-Ag & 96.5 \\
3 & P-HDTMS & 114.5 \\
4 & P-Ag-HDTMS & 109.0 \\
\hline
\end{tabular}




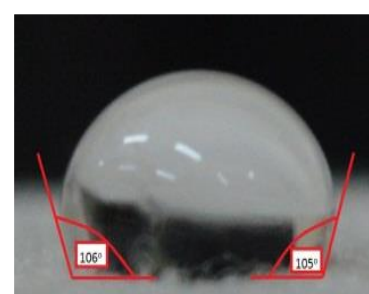

(a)

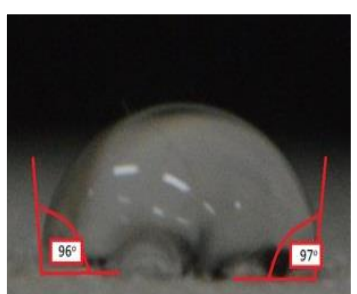

(b)

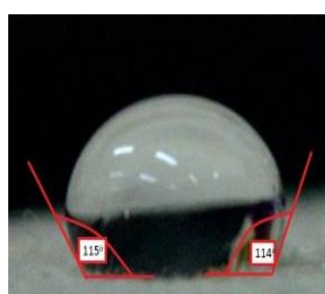

(c)

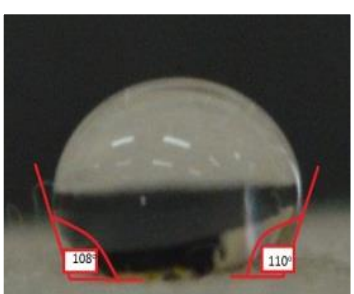

(d)

Figure 3. Contact Angle of P (a); P-Ag (b); P-HDTMS (c); P-Ag-HDTMS (d)

The contact angle test also showed that the contact angle of polyester fibers decreased. It was caused by the addition of silver nanoparticles as an antibacterial material. Deposit of silver nanoparticles into the polyester can cause a decreasing of a contact area between HDTMS and polyester. Thus HDTMS can not coat on surface of polyester. Modification of silver nanoparticles can cause a decreasing of the contact angle of polyester fibers without and with modification by the compound of HDTMS. Thus the presence of silver nanoparticles can reduce hydrophobic properties of polyester fibers.

\section{Antibacterial Activities of Polyester Fiber}

Figure 4a shows antibacterial activities of polyester fibers without and with modification against E.coli and Figure 4b shows antibacterial activities of polyester fibers without and with modification against $S$. aureus. All samples show antibacterial activities except $\mathrm{P}$ and P-HDTMS. Samples polyesters almost do not perform antibacterial activities against E.coli but show significant antibacterial activities against $S$. aureus. Antibacterial activities of samples P-HDTMSs against $S$. aureus are very low but are more against E.coli.

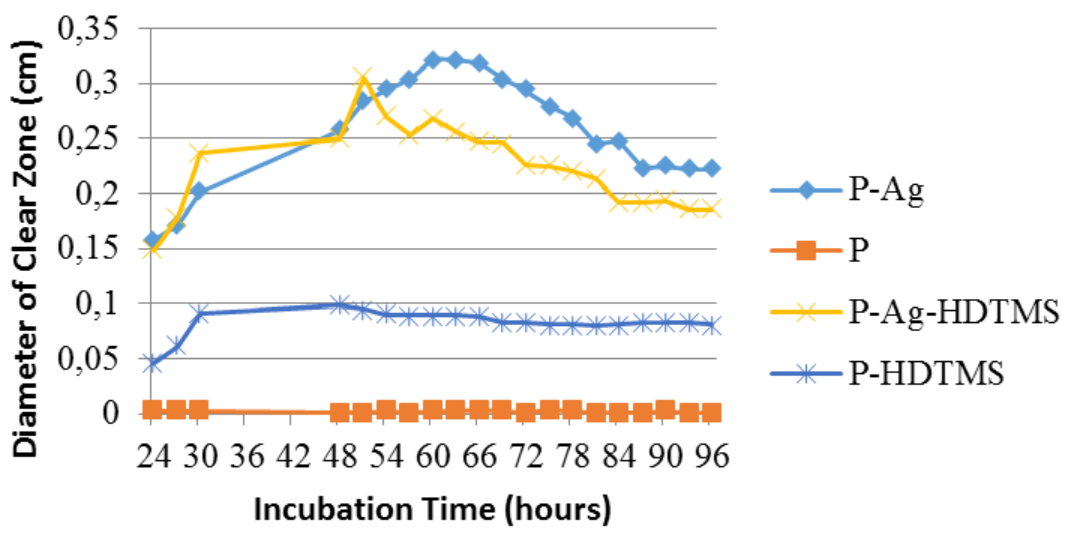

Figure 4a. Inhibiting Activities of Polyester Fiber without and with Modification against Escherichia coli ATCC 35218

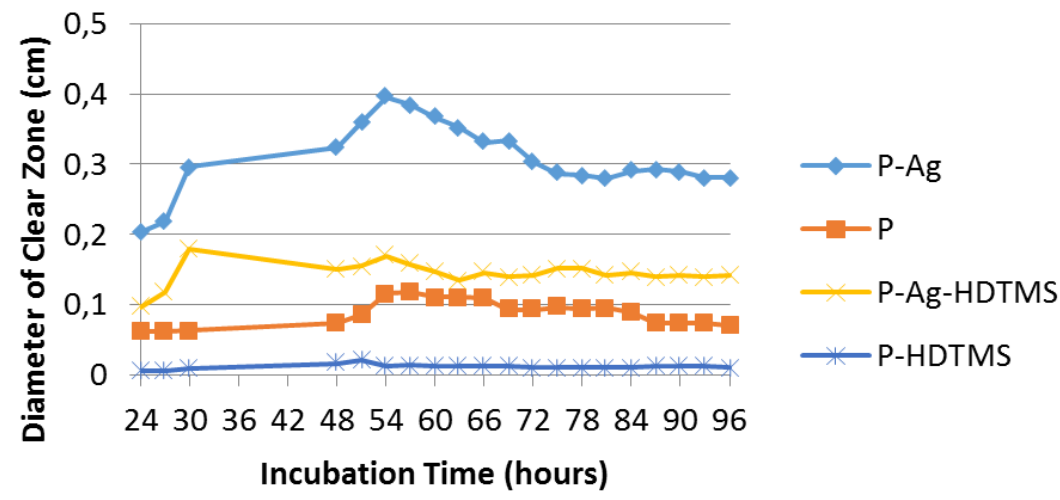

Figure 4b. Inhibiting Activities of Polyester Fiber without and with Modification against Staphylococcus aureus ATCC 25923 


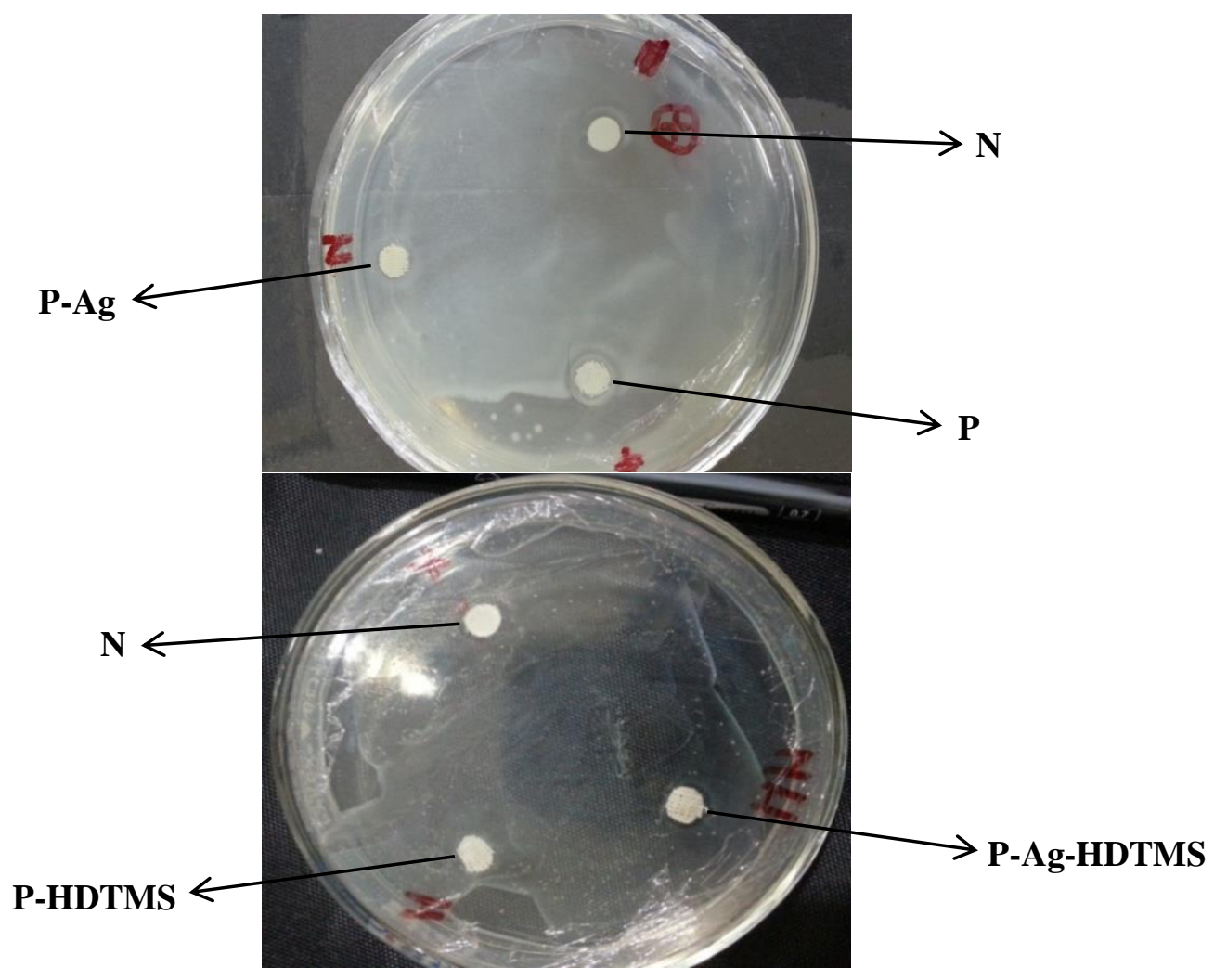

Figure 5a. The Clear Zone of Polyester Fiber Before and After Modification against Staphylococcus aureus ATCC 25923

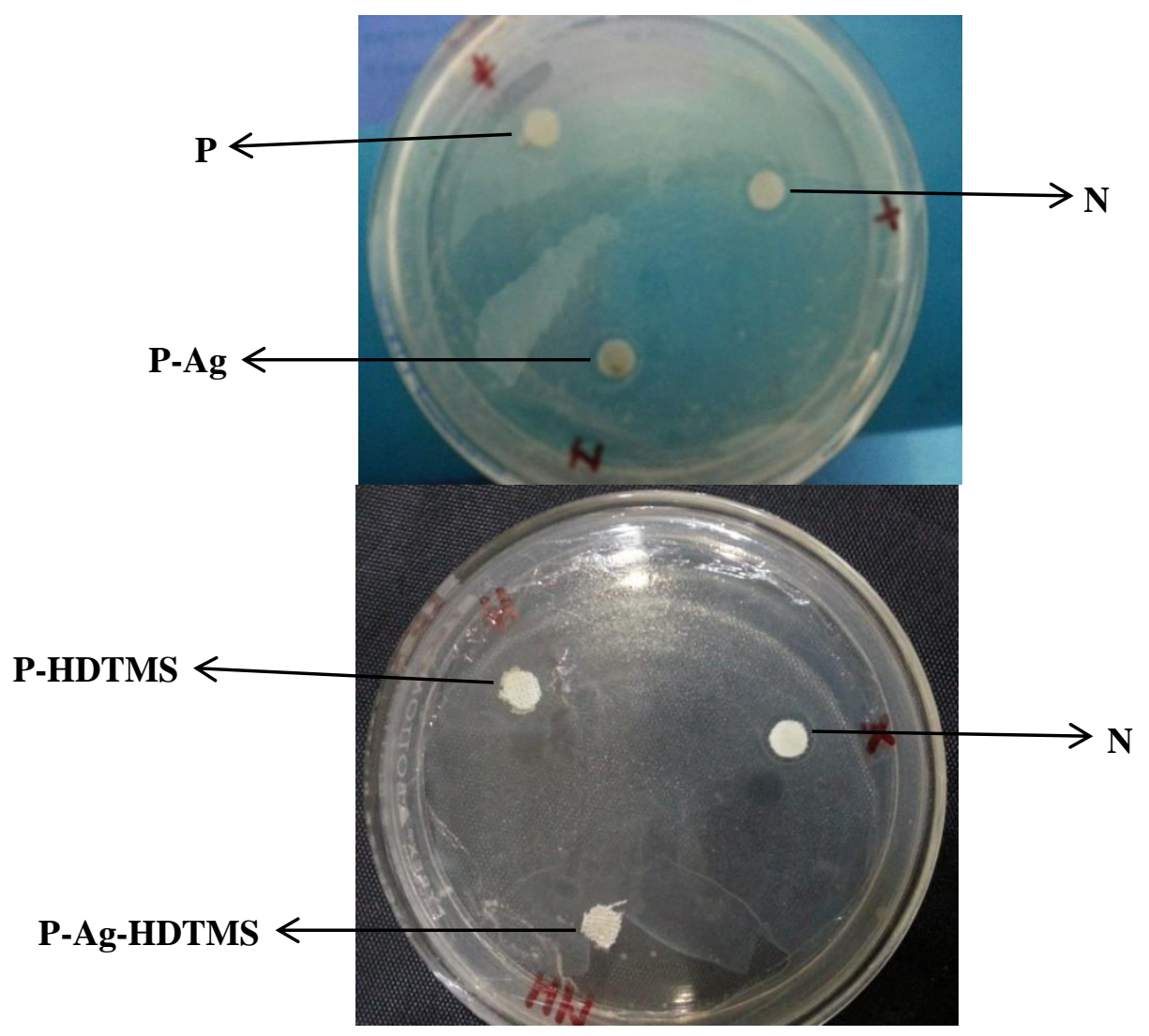

Figure 5b. The Clear Zone of Polyester Fiber Before and After Modification against Escherichia coli ATCC 35218 
Figure 4 shows that the samples which deposited with silver nanoparticles have the highest antibacterial activity. The silver nanoparticles are attached to the bacterial cell membrane is very possible. Silver nanoparticles react with sulfur protein and phosphorus-containing DNA in a bacterial cell. The reaction causes a changing morphological in bacterial cells, DNA damage, and respiratory problems, so the bacteria die (Zhang et al., 2014).

Figure 5a and Figure 5b shows the clear zone of polyester fiber before and after modification. ANOVA test to the diameter of the clear zone of sample types (treatment) in inhibiting the growth of Escherichia coli and Staphylococcus aureus showed sig 0.00 (P $<0.05$ ), as well as on further testing LSD showed the differences significant in the two types of bacteria (Table 3).

Further LSD test was conducted to determine the differences among the four types of samples. Data to be tested using LSD should be declared significantly different at ANOVA test to obtain valid test results. Table 3 shows the results of LSD test for antibacterial activity against $E$. coli and $S$. aureus. The sixth combination of sample type showed a significant difference regarding antibacterial activity against $E$. coli and S. aureus.

Based on analysis using Post Host Duncan indicated that all samples have differences antibacterial activity in inhibiting the growth of bacteria Escherichia coli ATCC 35218 and Staphylococcus aureus ATCC 25923 significantly. T-test results showed that all types of samples showed a significance value of less than 5\% error level (0.05), indicating a significant difference in antibacterial activity against Escherichia coli
ATCC 35218 and Staphylococcus aureus ATCC 25923.

Thus, there is a difference in the antibacterial activity between polyester fiber with and without modification against $E$. coli and $S$. aureus. This difference is influenced by the characteristics of a cell wall of Grampositive bacteria and gram-negative. S.aureus as gram-positive bacteria have a few layers of peptidoglycan join to form a thick and rigid structure, while $E$. coli is a gram-negative bacteria have a thin layer of peptidoglycan and outer membrane protected (Shagam, 2006 and Wheelis, 2007).

The cell walls of gram-positive bacteria also contain acids teichoic, consisting of $-\mathrm{OH}$ groups (such as ribitol and alcohol) and phosphate. A variety of functional groups here that have an important role in the interaction of silver nanoparticles with bacteria. It leads to more polyester effectively as an antibacterial against Staphylococcus aureus (Wheelis, 2007).

The mechanism of antibacterial activity can be explained by the interaction of silver with the bacteria that make up the protein corona (Figure 6). When the silver nanoparticles are mixed with bacteria in the culture medium, in the first phase of silver nanoparticles join with salt and proteins to form Protein Corona. Protein Corona will be close and attached to the bacterial cell wall and then destroyed it so that the penetration could occur. Once inside, the nanoparticles are still in the form of protein corona immediate release of silver ions. Silver ions will destroy the membrane of bacteria and cause the death of bacteria (Rai, Yadav, and Gade, 2009; Jin, Xu, Dong, Lan, Jiang, and Liu, 2015).

Table 3. Interpretation of LSD Test: Diameter of Clear Zone of Type Samples against Staphylococcus aureus ATCC 25923 and Escherichia coli ATCC 35218

\begin{tabular}{|c|c|c|}
\hline \multirow{2}{*}{ Variable (Type of Sample) } & \multicolumn{2}{|c|}{ Conclusion } \\
\hline & E.coli & S.aureus \\
\hline$(\mathrm{P})-(\mathrm{P}-\mathrm{Ag})$ & Significant & Significant \\
\hline (P) $-(\mathrm{P}-\mathrm{HDTMS})$ & Significant & Significant \\
\hline (P) $-(\mathrm{P}-\mathrm{Ag}-\mathrm{HDTMS})$ & Significant & Significant \\
\hline (P-Ag) - (P-HDTMS) & Significant & Significant \\
\hline$(\mathrm{P}-\mathrm{Ag})-(\mathrm{P}-\mathrm{Ag}-\mathrm{HDTMS})$ & Significant & Significant \\
\hline (P-HDTMS) - (P-Ag-HDTMS) & Significant & Significant \\
\hline
\end{tabular}




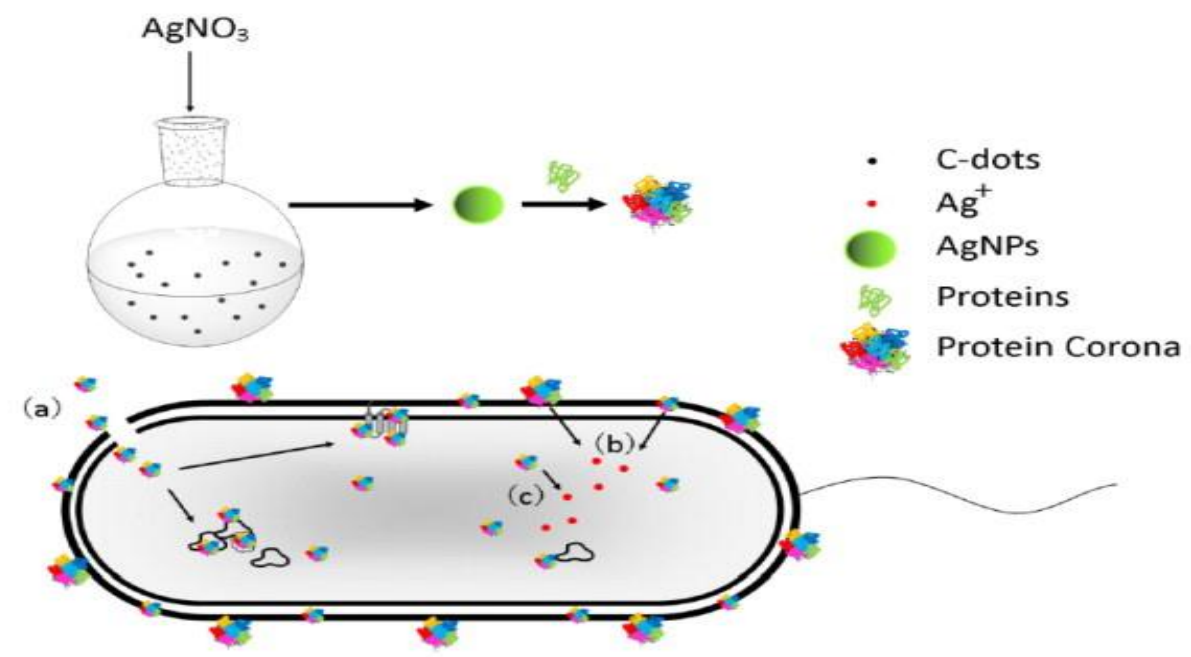

Figure 6. The Mechanism of the Formation of the Protein Corona (Jin et al., 2015)

\section{CONCLUSION}

Silver nanoparticles decrease hydrophobicity polyester fiber without and with the addition of HDTMS. The addition of HDTMS compounds increases the hydrophobicity properties of polyester fibers without and with the addition of silver nanoparticles. Modifications with silver nanoparticles and HDTMS increase antibacterial activity of polyester fiber against Staphylococcus aureus ATCC 25923 and Escherichia coli ATCC 35218. There are significant differences regarding the antibacterial activity of polyester fibers with and without modifications against Staphylococcus aureus ATCC 25923 and Escherichia coli ATCC 35218.

\section{ACKNOWLEDGEMENTS}

The authors thank the finance support from Ministry of Research, Technology, and Higher Education of the Republic Indonesia through project Fundamental Research 2017.

\section{REFERENCES}

Ahmad, M., Tay, M.Y., Shameli, K., Hussein, M.Z., \& Lim, J.J. (2011). Green Synthesis and Characterization of Silver/Chitosan/Polyethylene Glycol Nanocomposites without any Reducing Agent. International Journal of Molecular Science, 12(1), 4872-4884.

Ariyanta, H.A., Wahyuni, S., \& Priatmoko, S. (2014). Preparasi Nanopartikel Perak dengan Metode Reduksi dan Aplikasinya sebagai Antibakteri
Penyebab Infeksi. Indonesian Journal of Chemical Science, 3(1), 1-6.

Arkles, B.(2006). Hydrophobicity, Hidrophilicity, and Silanes. Paint and Coating Industry, 22(10), 114-135.

Boroumand, M. N., Montazer, M., Simon, F., Liesiene, J., Šaponjic, Z., \& Dutschk, V. (2015). Novel Method for Synthesis of Silver Nanoparticles and Their Application on Wool. Applied Surface Science, 347(1): 477-483.

Crespo, J., García-Barrasa, J., López-deLuzuriaga, J.M., \& Monge, M. (2012). Organometallic Approach to PolymerProtected Antibacterial Silver Nanoparticles: Optimal Nanoparticle Size-Selection for Bacteria Interaction. Journal of Nanoparticle Research., 14(1), 1281-1293.

Duran, N. \& Marcato, P.D. (2007). Antibacterial Effect of Silver Nanoparticles Produced by Fungal Process on Textile Fabrics and Their Effluent Treatment. Journal of Biomedical Nanotechnology, 3(2), 203208.

El-Khatib, E.M. (2012). Antimicrobial and Self-cleaning Textiles using Nanotechnology. Research Journal of Textile and Apparel., 16(3), 156-174.

Gao, S., Watanabe, H., Nakane, K., \& Zhao, K. (2016). Fabrication and Characterization of Superhydrophobic and Superhydrophilic Silica Nanofibers Mats with Excellent Heat Resistance. Journal of Mining and Metallurgy, Section B: Metallurgy, 52(1), 87-92. 
Guo, P., Zhai, S., Xiao, Z., \& An, Q. (2015). One-step Fabrication of Highly Stable, Superhydrophobic Composites from Controllable and Low-cost PMH/TEOS Sols for Efficient Oil Cleanup. Journal of Colloid and Interface Science, 446(1), 155-162.

Guzman, M., Dille, J., \& Godet, S. (2012). Synthesis and Antibacterial Activity of Silver Nanoparticles against GramPositive and Gram-Negative Bacteria. Nanomedicine, 8(1), 37-45.

Haryono, A. \& Harmami, S.B. (2010). Aplikasi Nanopartikel Perak pada Serat Katun sebagai Produk Jadi Textil Antimikroba. Jurnal Kimia Indonesia, 5(1), 1-6.

Haryono, A., Sondari, D., Harmami, S.B., \& Randy, M. (2008) Sintesa Nanopartikel Perak dan Potensi Aplikasinya. Jurnal Riset Industri, 2(3), 156-163.

Hassan, M., Qashqary, K., Hassan, H.A., Shady, E., \& Alansary, M. (2012). Influence of Sportware Fabrics Properties on the Health and Performance of Athlete. Fibers \& Textile in Eastern Europe, 20(4), 8288.

Jiang, S.X., Qin, W.F., \& Zhang, L. (2010). Surface Functionalization of Nanostructured Silver-coated Polyester Fabric by Magnetron Sputtering. Surface \& Coating Technology, 204(1), 3662-3667.

Jin, J-C., Xu, Z-Q., Dong, P., Lan, J-Y., Jiang, F-L., \& Liu, Yi. (2015). One-step Synthesis of Silver Nanoparticles using Carbon Dots as Reducing and Stabilizing Agents and Their Antibacterial Mechanism. DOI:10.1016/j.carbon.2015.05.084.

Junaidi, A.B., Wahyudi, A., \& Umaningrum, U. (2015). Kajian Sintesis Nanopartikel Perak pada Komposit Kitosan dan Polietilena Glikol : Efek Jenis Agen Pereduksi Organik. Prosiding Seminar Nasional. Jurusan Kimia FMIPA Universitas Negeri Semarang, Semarang.

Kavitha, C. \& Dasan, K.P. (2013). Nanosilver/hyperbranched Polyester (HBPE): Synthesis, Characterization, and Antibacterial Activity. Journal of Coating Technology and Research, 10(5), 669-678.
Rai, M., Yadav, A., \& Gade, A. (2009). Silver Nanoparticles as a New Generation of Antimicrobial. Biotechnology Advance, 27(1), 76-83.

Shateri-Khalilabad, M. \& Yazdanshenas, M. E. (2010). Superhydrophobic Antibacterial Cotton Textiles. Journal of Colloid and Interface Science, 351(1), 293-298.

Saputra, A. H.., Haryono, A., Laksmono, J. A., \& Anshari, M. H. (2011). Preparasi Koloid Nanosilver dengan Berbagai Jenis Reduktor sebagai Bahan Antibakteri. Jurnal Sains Materi Indonesia, 12(3), 202-208.

Shateri-Khalilabad, M. \& Yazdanshenas, M. E. (2013). One-pot Sonochemical Synthesis of Superhydrophobic OrganiInorganic Hybrid Coating on Cotton Cellulose. Cellulose, 20(1), 3039-3051.

Wheelis, M. (2007). Principles of Microbiology. Sudbury, CA:Jones \& Bartlett Publishers.

Xue, C-H., Chen, J., Yin, W., Jia, S-T., JianZhong, M. (2012). Superhydrophobic Conductive Textiles with Antibacterial Property by Coating Fibers with Silver Nanoparticles. Applied Surface Science, 258(1), 2468-2472.

Yu, M., Gu, G., Meng, W-D., \& Qimg, F-L. (2007). Superhydrophobic Cotton Fabric Coating Based on a Complex layer of Silica Nanoparticles and Perfluorooctylated Quaternary Ammonium Silane Coupling Agent. Applied Surface Science, 253(1), 36693673.

Zhang, G., Liu, Y., Gao, X., \& Chen, Y. (2014). Synthesis of Silver Nanoparticles and Antibacterial Property of Silk Fabrics Treated by Silver Nanoparticles. Nanoscale Research Letters, 9(1), 216-223.

Zhang, Y., Liu, X., Jiang, P. \& Quek, S. Y. (2016). Antibacterial Activity and Mechanism of Cinnamon Essential oil against Escherichia coli and Staphylococcus aureus. Food Control, 59(1), 282-289. 